\title{
The Influence of Distance Learning use Lectora Inspire-Based Interactive Learning Media on Students' Mathematical Problem Solving Abilities In Primary Schools
}

\author{
Eko Fajar Suryaningrat, Widdy Sukma Nugraha, Lutfy Sy'ari, Muhammad \\ Nurjamaludin
}

Institut Pendidikan Indonesia

ekofajar@institutpendidikan.ac.id

\section{Article History}

accepted 05/11/2020

\begin{abstract}
The purpose of this study was to find out how much distance learning use Interactive learning media based on lectora inspire influence on the learning process and Mathematical Problem Solving Abilities. This research uses collaborative research between lecturers, students, and teachers in 2020 at one of the primary schools in west Java. This research was a quasiexperiment research with Pretest-Posttest Control Design. Data collection techniques tests. the result of the research is to find out how the impact of the use of learning media lectora inspire based interactive on students approach is proven to improve Mathematical problem solving abilities in primary schools. The conclusion of research was that there was a difference of effect of distance learning use lectora inspire-based interactive learning media on the Mathematical Problem Solving Abilities of students between control and experiment classes and Students' attention was also more focused so it is easier to concentrate on receiving lessons.

Keywords: Lectora inspire-based interactive learning media, distance learning, mathematical problem solving abilities
\end{abstract}

\begin{abstract}
Abstrak
Tujuan penelitian ini adalah untuk mengetahui seberapa besar pengaruh pembelajaran jarak jauh menggunakan media pembelajaran interaktif berbasis lectora inspire terhadap proses pembelajaran dan Kemampuan Pemecahan Masalah Matematika. Penelitian ini menggunakan penelitian kolaboratif antara Dosen, Mahasiswa, dan Guru tahun 2020 di salah satu sekolah dasar di Jawa Barat. Penelitian ini merupakan penelitian quasi-experiment dengan PretestPosttest Control Design. pengumpulan data menggunakan instrument tes. Hasil penelitian ini adalah untuk mengetahui bagaimana pengaruh pembelajaran jarak jauh menggunakan media pembelajaran interaktif berbasis lectora inspire terbukti dapat berpengaruh terhadap kemampuan pemecahan masalah matematika siswa di sekolah dasar. Kesimpulan dari penelitian ini adalah terdapat perbedaan pengaruh Pembelajaran jarak jauh menggunakan media pembelajaran interaktif berbasis lectora inspire pada kemampuan pemecahan masalah matematika antara kelas kontrol dan eksperimen serta perhatian siswa juga lebih terarah sehingga lebih mudah berkonsentrasi menerima pelajaran.
\end{abstract}

Kata kunci: pembelajaran interaktif berbasis lectora inspire, pembelajaran jarak jauh, kemampuan pemecahan masalah matematik

Social, Humanities, and Education Studies (SHEs): Conference Series p-ISSN 2620-9284 https://jurnal.uns.ac.id/shes

e-ISSN 2620-9292 


\section{PENDAHULUAN}

Proses pembelajaran yang dilakukan dilingkungan sekolah dan ruang kelas telah berubah, ini disebabkan oleh pandemic COVID-19. Proses pembelajaran yang biasa terpusat menjadi belajar dirumah dikarenakan penerapan social distancing untuk mengatasi penyebaran COVID-19. Menteri Pendidikan dan Kebudayaan Republik Indonesia mengeluarkan Surat Edaran Nomor 4 Tahun 2020 Tentang Pelaksanaan Kebijakan Pendidikan Dalam Masa Darurat Penyebaran Coronavirus Disease (Covid19) proses belajar dari rumah dilaksanakan dengan ketentuan sebagai berikut :

a. Belajar dari rumah melalui pembelajaran daring/jarak jauh dilaksanakan untuk memberikan pengalaman belajar yang bermakna bagi siswa, tanpa terbebani tuntutan menuntaskan seluruh capaian kurikulum untuk kenaikan kelas maupun kelulusan;

b. Belajar dari rumah dapat difokuskan pada pendidikan kecakapan hidup antara lain mengenai pandemic Covid-19;

c. Aktivitas dan tugas pembeljaran belajar dari rumah dapat bervariasi antarsiswa, sesuai minat dan kondisi masing-masng, termasuk mempertimbangkan kesenjangan akses/fasilitas belajar dirumah;

d. Bukti atau prosuk aktivitas belajar dari rumah diberi umpan balik yang bersifat kualitatif fan berguna dari guru, tanpa diharuskan memberi skor/nilai kuantitatif.

Surat edaran menteri pendidikan dan kebudayaan ini berdapak pada proses pembelajaran yang semula adalah tatap muka menjadi pembelajaran jarak jauh (PJJ) dalam jaringan (daring) dengan system online.

Pendidikan jarak jauh sendiri telah diatur dalam UU Sisdiknas 2003 Bagian Ke-10 Pasal 31 yang berbunyi: (1). Pendidikan jarak jauh dapat diselenggarakan pada semua jalur, jenjang, dan jenis pendidikan. (2). Pendidikan jarak jauh berfungsi memberikan layanan pendidikan kepada kelompok masyarakat yang tidak dapat mengikuti pendidikan secara tatap muka atau reguler. (3). Pendidikan jarak jauh diselenggarakan dalam berbagai bentuk, modus, dan cakupan yang didukung oleh sarana dan layanan belajar serta sistem penilaian yang menjamin mutu lulusan sesuai dengan standar nasional pendidikan. Pembelajaran jarak jauh bukan hal baru dalam dunia pendidikan Indonesia, pendidikan jarak jauh sudah di atur dalam UU Sisdiknas dari tahun 2003.

Moore \& Kearsley, (2012) mengungkapkan bahwa adanya keterpisahan secara fisik antarpeserta didik dan antara peserta didik dengan pengajar merupakan salah satu karakteristik dari pendidikan jarak jauh. Ini mengakibatkan kurang terjadinya interaksi antara pendidik dengan peserta didik. Pendidik tidak dapat membimbing dan mengawasi peserta didik secara individual dengan teratur pada pembelajaran jarak jauh karena dipisahkan jarak antara pendidik dengan peserta didik.

Matematika memiliki tujuan umum berdasarkan NCTM yaitu: komunikasi matematis, penalaran matematis, pemecahan masalah matematis, koneksi matematis, representasi matematis (Widodo;2017). Siswa dalam belajar matematika diharapkan memiliki kemamapuan-kemampuan yang ada dalam NCTM. Sejalan dengan Winarni dan Harmini (2015) tujuan belajar matematika yang tertera dalam kurikulum mata pelajaran matematika sekolah pada semua jenjang pendidikan, yaitu: mengarah pada kemampuan siswa pada pemecahan masalah yang dihadapi dalam kehidupan sehari-hari. Kemampuan pemecahan masalah merupakan salah satu kemampuan yang harus dimilki siswa. Maka pada pembelajaran jarak jauh pendidik harus memperkatikan.

Berdasarkan hasil obsevasi yang dilakuakan oleh peneliti di SDN 1 Cigintung, siswa dalam mengikuti pembelajaran jarak jauh merasa jenuh karena kurangnya interaksi yang terjadi antara pendidik dan peserta didik. Hal ini mengakibatkan pada hasil belajar mereka yang menurun dan peserta didik sulit untuk menyelesaikan soal latihan yang mengukur kemampuan pemecahan masalah. Jika dilihat dari pringkat Hasil (PISA) oleh OECH mengenai kemampuan pemecahan masalah siswa pada 
domain pemecahan masalah matematis menunjukkan bahwa siswa Indonesia berada pada peringkat 64 dari 65 negara peserta (Putri, 2016). Maka diperlukan pembelajaran jarak jauh yang bisa mengakomodir interaksi antara peserta didik dengan pendidik. Jangan sampai kondisi saat ini menurunkan kualitas pembelajaran dan berimbas pada kurangnya kemampuan pemecahan masalah siswa.

Teknologi memiliki peranan penting dalam kelancaran proses pendidikan jarak jauh. Munir (2009) menerangkan bahwa awal mula pembelajaran jarak jauh adalah sistem modul tertulis, kemudian dengan berkembangnya teknologi informasi muncullah berbagai media berbantuan komputer, audio, video, media cetak, multimedia, dan internet. Pembelajaran e-learning artinya bukan hanya dilakukan menggunakan koneksi internet, namun dapat juga menggunakan media elektronik seperti radio dan televisi. Berdasarkan keterangan ahli diatas memungkinkan pembelajaran jarak jauh menggunakan media, sebagai alat utuk menyampaikan materi kepada siswa sehingga terjadi interaksi antara pendidik dan peserta didik. Untuk mencapai tujuan pembelajaran yang diharapkan dalam proses mentransfer ilmu melalui pembelajaran jarak jauh, pendidik menggunakan media interaktif agar proses pembelajaran jarak jauh tidak jenuh dan membuat siswa stress. Pendidik dapat mengoptimalkan penggunaan media pembelajaran yang tepat. Berdasarkan apa yang dikemukakan Hamalik (2008) "Media pembelajaran merupakan salah satu komponen sistem pembelajaran yang mempunyai peranan penting dalam menunjang kualitas proses belajar-mengajar". Hal ini terjadi karena media pembelajaran mampu meningkatkan efektifitas dan efisiensi dalam mencapai tujuan pembelajaran. Penggunaan media dalam proses pembelajaran dapat menarik minat dan memotivasi siswa, juga dapat meningkatkan kemampaun pemecahan matematik matematik siswa. Berdasarkan permasalahan yang berkembang diatas, maka peneliti ingin melihat bagaimana kemampuan pemecahan matematik siswa melalui penggunaan media pembelajaran interaktif berbasis Lectora inspire pada pembelajaran matematika di Sekolah Dasar.

\section{METODE}

Metode yang digunakan dalam penelitian ini adalah quasi-experiment dengan desain non equivalent control group design. Desain ini digambarkan seperti berikut (Sugiono,2013).

\begin{tabular}{|c|c|c|c|}
\hline Kelompok & & Perlakuan & Postet \\
\hline Eksperimen & & $\mathrm{T}_{1}$ & $\mathrm{~T}_{2}$ \\
\hline Kontrol & & $\mathrm{T}_{1}$ & $\mathrm{~T}_{2}$ \\
\hline \multirow[t]{3}{*}{ Keterangan } & $\mathrm{E}:$ & \multicolumn{2}{|l|}{ Kelompok eksperimen } \\
\hline & $\begin{array}{l}\text { K : } \\
\text { T1: } \\
\text { T2: }\end{array}$ & \multicolumn{2}{|c|}{$\begin{array}{l}\text { Kelompok Kontrol } \\
\text { Tes awal (pretest) } \\
\text { Tes akhir (postest) }\end{array}$} \\
\hline & $X:$ & $\begin{array}{l}\text { Penerapan Pembelajaran } \\
\text { menggunakan media pembelaj } \\
\text { berbasis Lectora inspire }\end{array}$ & $\begin{array}{l}\text { Jarak Jauh } \\
\text { jaran interaktif }\end{array}$ \\
\hline
\end{tabular}


Penelitian ini selain terdiri dari variable bebas dan variabel terikat. Dua kelas ditentukan secara purposif yaitu $\mathrm{V}$ A dan $\mathrm{V}$ B. Kelas $\mathrm{V} B$ sebagai kelas kontrol (kelas yang memperoleh pembelajaran konvensional)dan kelas $V$ A sebagai kelas eksperimen (kelas yang memperoleh Pembelajaran Jarak Jauh menggunakan media pembelajaran interaktif berbasis Lectora inspire).

\section{HASIL DAN PEMBAHASAN}

Deskripsi statistik meliputi rata-rata, standar deviasi, dan jumlah siswa berdasarkan pembelajaran yang digunakan. Hasil deskripsi tes awal (pretest) maupun tes akhir (posttest) dan gain ternormalisasi kemampuan komunikasi matematis kelas eksperimen dan kelas kontrol disajikan pada Tabel 4.1 berikut:

Tabel 1. Deskripsi Hasil Tes Awal (Pretest) dan Tes Akhir (Posttest) Kemampuan Pemecahan Masalah Matematis Siswa

\begin{tabular}{lcccccccc}
\hline Hasil tes & & \multicolumn{3}{c}{ eksperimen } & \multicolumn{5}{c}{ Kontrol } \\
& $\mathrm{n}$ & $x_{\text {maks }}$ & $x_{\min }$ & $\bar{x}$ & $\mathrm{n}$ & $x_{\text {maks }}$ & $x_{\min }$ & $\bar{x}$ \\
& & & & & & & & \\
\hline Pretest & 29 & 45 & 10 & 25,9 & 30 & 40 & 5 & 24,17 \\
Posttest & & 95 & 45 & 70,0 & & 90 & 38 & 61,00
\end{tabular}

Dari Tabel 1 diatas, terlihat bahwa nilai rata-rata pretest dan nilai rata-rata posttest pada kelas eksperimen lebih besar daripada kelas kontrol. Meskipun demikian belum dapat diambil kesimpulan bahwa proses pembelajaran di kelas eksperimen lebih baik daripada kelas kontrol. Namun kecenderungan tersebut memerlukan adanya pengujian lebih lanjut dengan uji statistik.

Analisis Data Tes Awal (Pretest) telah diperoleh dari kelas eksperimen dan kelas kontrol terlebih dahulu diuji normalitas sebaran datanya dan kedua data tidak berdistribusi normal, maka dilanjutkan dengan uji mann Whitney.dengan hasil yang terlihat pada table 2 .

Tabel 2. Deskripsi Hasil Uji Mann-Whitney Data Pretest

\begin{tabular}{ccccccc}
\hline Nilai $\mathbf{U}$ & $\mu_{u}$ & $\sum T$ & $\delta_{u}$ & Zhitung & Ztabel & Kesimpulan \\
\hline 466,5 & 435 & 143,5 & 65,68 & 0,48 & 1,96 & Ho diterima \\
\hline
\end{tabular}

Menurut Sundayana (2010:152) "terima Ho jika $-Z_{\text {tabel }} \leq Z_{\text {hitung }} \leq Z_{\text {tabel. }}$. Dari tabel 2 dapat diketahui bahwa nilai $Z_{\text {hitung }}$ lebih besar dari $Z_{\text {tabel, }}$, sehingga dengan uji dua pihak dan taraf signifikansi 0,05 maka Ho diterima dan Ha ditolak. Sehingga dapat disimpulkan bahwa tidak terdapat perbedaan kemampuan pemecahan masalah matematis antara siswa yang mendapat Pembelajaran jarak jauh menggunakan media pembelajaran interaktif berbasis Lectora inspire dengan siswa yang tidak mendapatkan Pembelajaran jarak jauh menggunakan media pembelajaran interaktif berbasis Lectora inspire.

Analisis data tes akhir (posttest) data yang telah diperoleh, terlebih dahulu diuji normalitas sebaran datanya. Pengujian normalitas data posttest ini dilakukan dengan menggunakan Uji Chi-kuadrat. Hasil perhitungan dari pengujian normalitas selengkapnya terdapat pada Tabel 3 berikut. 
Tabel 3. Hasil Uji Normalitas Data Posttest

\begin{tabular}{|c|c|c|c|}
\hline \multirow[b]{2}{*}{ Tes Awal } & \multicolumn{2}{|c|}{ Nilai $\chi 2$} & \multirow{2}{*}{ Interpretasi } \\
\hline & $\chi^{2}$ hitung & $\chi^{2}$ tabel & \\
\hline $\begin{array}{c}\text { PJJ menggunakan media } \\
\text { pembelajaran interaktif berbasis } \\
\text { Lectora inspire }\end{array}$ & 6,33 & 7,82 & Berdistribusi Normal \\
\hline $\begin{array}{l}\text { PJJ Tidak menggunakan media } \\
\text { pembelajaran interaktif berbasis } \\
\text { Lectora inspire }\end{array}$ & 4,60 & 7,82 & Berdistribusi Normal \\
\hline
\end{tabular}

Dari Tabel 3 dapat diketahui bahwa pada kedua kelas kelas diperoleh nilai $\mathrm{X}_{\text {hitung }}<$ nilai $X_{\text {tabel. }}$ Sehingga dengan taraf signifikansi 0,05 data skor posttest tersebut berdistribusi normal. Karena sebaran kedua data berdistribusi normal, maka dilanjutkan dengan Uji Homogenitas. Uji Homogenitas selengkapnya dapat terlihat pada table 4.4 berikut.

Tabel 4. Banyak Data, Rata-rata dan Simpangan Baku

\begin{tabular}{cccc}
\hline Kelompok & Banyak Data & Rata-rata & Simpangan baku \\
\hline $\begin{array}{c}\text { PJJ dengan menggunakan } \\
\text { media pembelajaran interaktif } \\
\text { berbasis Lectora inspire }\end{array}$ & 29 & 70 & 15,28 \\
$\begin{array}{c}\text { PJJ Tidak menggunakan media } \\
\text { pembelajaran interaktif } \\
\text { berbasis Lectora inspire }\end{array}$ & 30 & 61 & 14,38 \\
\hline
\end{tabular}

$\mathrm{F}_{\text {hitung }}<\mathrm{F}_{\text {tabel }}$ maka kedua varians homogen. Karena kedua data berdistribusi normal dan kedua varians homogen, maka dilanjutkan dengan uji t. Uji t selengkapnya dapat terlihat pada table 4.5 berikut.

Tabel 5. Deskripsi Hasil Uji t Data Posttest

\begin{tabular}{cccc}
\hline Simpangan Baku Gabungan & thitung & ttabel & Kesimpulan \\
\hline 14,83 & 2,3300 & 2,0032 & Ho ditolak dan Ha diterima \\
\hline
\end{tabular}

Menurut Sundayana (2010:152) "terima Ho jika $-t_{\text {tabel }} \leq t_{\text {hitung }} \leq \mathrm{tt}_{\text {abell }}$ ". Dari tabel 4.5 dapat diketahui bahwa nilai $t_{\text {hitung }}>$ dari $t_{\text {tabel }}$ l, sehingga dengan taraf signifikansi 0,05 maka Ho ditolak dan Ha diterima. Sehingga dapat disimpulkan bahwa: Terdapat perbedaan kemampuan pemecahan masalah matematis antara siswa yang mendapat pendekatan Pembelajaran Jarak Jauh dengan menggunakan media pembelajaran interaktif berbasis Lectora inspire dengan siswa yang Pembelajran jarak jauh tidak menggunakan media pembelajaran interaktif berbasis Lectora inspire.

\section{SIMPULAN}

Berdasarkan hasil analisis data dan pembahasan yang telah dikemukakan maka diperoleh kesimpulan sebagai berikut: Terdapat perbedaan kemampuan pemecahan masalah matematis antara siswa yang mendapat pendekatan Pembelajaran Jarak Jauh dengan menggunakan media pembelajaran interaktif berbasis Lectora inspire dengan siswa yang Pembelajran jarak jauh tidak menggunakan media pembelajaran interaktif berbasis Lectora inspire. 


\section{DAFTAR PUSTAKA}

Menteri Pendidikan dan Kebudayaan Republik Indonesia.(2020) Surat Edaran Nomor 4 Tahun 2020. Jakarta : penulis

Depdiknas .(2003). Undang-undang RI No.20 tahun 2003.tentang system pendidikan nasional. Jakarta: Penulis

Moore, G.M. \& Kearsley, G. (2012). Distance Education: a System View of Online Learning. Third Edition. Belmont, CA: Wadswoth, Cengage Learning.

Widodo. (2017). Metodologi Penelitian, Populer \& Praktis. Jakarta: PT Raja Grafindo Persada.

Winarni, Endang Setyo dan Sri Harmini. (2011) . Matematika Untuk PGSD. Bandung: PT Remaja Rosdakarya.

Agustina, Putri; Saputra Alanindra. (2016). "Analisis Keterampilan Proses Sains (KPS) Dasar Mahasiswa Calon Guru Biologi Pada Mata Kuliah Anatomi Tumbuhan (Studi Kasus Mahasiswa Prodi Pendidikan Biologi FKIP UMS Tahun Ajaran 2015/2016)". Prosiding seminar nasional pendidikan sains (SNPS). surakarta: Universitas Muhammadiyah Surakarta.

Munir. (2009). Pembelajaran Jarak Jauh Berbasis Teknologi Informasi dan Komunikasi. Bandung: Alfabeta

hamalik, Oemar. (2008). Perencanaan Pengajaran Berdasarkan Pendekatan Sistem. Jakarta: Bumi Aksara.

Sugiyono. (2013). Metode Penelitian Pendidikan. Bandung: Alfabeta 